ISSN 1392-3196 / e-ISSN 2335-8947

Zemdirbyste-Agriculture, vol. 102, No. 4 (2015), p. 389-396

DOI 10.13080/z-a.2015.102.049

\title{
Nutritive value of spelt (Triticum aestivum spp. spelta L.) as influenced by the foliar application of copper, zinc and manganese
}

\author{
Katarzyna WOJTKOWIAK, Arkadiusz STĘPIEŃ \\ University of Warmia and Mazury in Olsztyn \\ Heweliusza 10-724 Olsztyn, Poland \\ E-mail: katarzyna.wojtkowiak@uwm.edu.pl
}

\begin{abstract}
The research determined crop yield, content of mineral nutrients $(\mathrm{Cu}, \mathrm{Zn}, \mathrm{Mn}$ and $\mathrm{Fe})$, protein and its composition in the grain of the spelt variety 'Schwabenkorn' as affected by the foliar application of micronutrients. A field experiment was carried out during 2011-2013 at the Research Station in Tomaszkowo (5372 N, $20^{\circ} 42$ E), Poland. $\mathrm{Cu}, \mathrm{Zn}$ and $\mathrm{Mn}$ and microelements together $(\mathrm{Cu}+\mathrm{Zn}+\mathrm{Mn})$ with mineral fertilisers were applied. Nitrogen $(\mathrm{N})$ was applied to all the plots in a dose of $90 \mathrm{~kg} \mathrm{ha}^{-1}$, triple superphosphate in a dose corresponding to $30.2 \mathrm{~kg} \mathrm{ha}^{-1}$ $\mathrm{P}$, and potassium salt in a dose of $83.1 \mathrm{~kg} \mathrm{ha}^{-1} \mathrm{~K}$. Copper $\left(1.0 \%\right.$ solution of $\left.\mathrm{CuSO}_{4} \times 5 \mathrm{H}_{2} \mathrm{O}\right)$, zinc $(1.0 \%$ solution of $\left.\mathrm{ZnSO}_{4} \times 7 \mathrm{H}_{2} \mathrm{O}\right)$ and manganese $\left(0.5 \%\right.$ solution of $\left.\mathrm{MnSO}_{4} \times 5 \mathrm{H}_{2} \mathrm{O}\right)$ were foliar-applied as water solutions at the stem elongation stage. The mineral fertilisation, including micronutrients (individually or in combination), changed the contents of mineral nutrients, protein and the composition of its individual fractions in the grain. It was observed that the grain had high $\mathrm{Cu}, \mathrm{Mn}$ and $\mathrm{Fe}$ content. The application of $\mathrm{Mn}$, as well as micronutrients used in combination $(\mathrm{Cu}+\mathrm{Zn}+\mathrm{Mn})$ as an addition to NPK fertilisation, increased the content of $\mathrm{Fe}, \mathrm{Zn}$ and $\mathrm{Mn}$ in spelt grain. The application of $\mathrm{Zn}$ increased $\mathrm{Fe}$ and $\mathrm{Zn}$ content, while the application of $\mathrm{Cu}$ increased the content of $\mathrm{Mn}$ in grain. The total protein content in spelt ranged from $12.4 \%$ to $13.5 \%$. Storage proteins proved to have the highest share in the total protein. Additional application of $\mathrm{Cu}, \mathrm{Zn}$ and micronutrients in combination had a positive impact on the gliadins:glutenins ratio. Foliar application of $\mathrm{Mn}$ increased the content of $\omega, \alpha / \beta, \gamma$ gliadins, and reduced that of low molecular weight glutenins. Foliar spraying with $\mathrm{Cu}$ reduced the content of $\alpha / \beta$ and $\omega$ gliadins. Supply of $\mathrm{Zn}$ decreased $\alpha / \beta$ content and increased the content of the high molecular weight glutenins fractions. The application of the micronutrients in combination reduced the content gliadin $\gamma$ and increased the content of high molecular weight and low molecular weight glutenins. The cultivation year was a significantly differentiating factor for the grain yield, mineral nutrient content ( $\mathrm{Fe}, \mathrm{Zn}$ and $\mathrm{Mn}$ ) and the content and composition of protein fractions (with the exception of high molecular weight glutenins).
\end{abstract}

Key words: gliadins, glutenins, micronutrients, protein composition, protein content, 'Schwabenkorn'.

\section{Introduction}

Spelt (Triticum aestivum spp. spelta L.) is one of the oldest wheat subspecies. Today, spelt is grown mainly on ecological farms in German-speaking countries and in Belgium, Italy, France and Central European countries (Akeret, 2005). This species has become interesting as a result of advantageous grain quality parameters, its use in production and the potential possibility to arouse consumer interest in new products with the addition of spelt flour. In many studies, the researchers presented the suitability of spelt grain and flour for bread making and the manufacturing of food products (Świeca et al., 2014). As regards nutrition, spelt grain is more valuable than bread wheat (Rachon', Szumiło, 2009). It is richer in protein, which is characterized by its relatively high biological value (Branković et al., 2015). The technological parameters of spelt flour are close to those of bread wheat flour and, in many respects, much like those of hard wheat grain. Spelt grain usually contains more wet gluten, which is characterized by higher flowability, i.e. a weaker gluten structure (Schober et al., 2006; Pruska-Kędzior et al., 2008). Among the elements of production technology during the vegetation period, mineral fertilisation with NPK, as well as organic fertilisers, affects the content of gluten proteins in grain, differentiating the content of gliadins, especially $\omega, \alpha / \beta$, $\gamma$ types and high molecular weight and low molecular weight glutenins (Konopka et al., 2007; Stępień, Wojtkowiak, 2013). The unique position of wheat among cereals can be attributed to gluten proteins (gliadins and glutenins). Their accumulation and interrelations affect such properties of dough as viscoelasticity and viscosity, as well as bread porosity. Dough rising and quality are affected by the composition of glutenins, especially HMW glutenins (Goesaert et al., 2005). 
Differences in grain quality may result from the genetic properties of the variety, habitat conditions and agrotechnology applied (Podolska, 2008; Cazzato et al., 2013). Compared to bread wheat, spelt grain contains more iron, zinc, copper, magnesium, potassium, sodium and selenium (Ruibal-Mendieta et al., 2005). In plant production, the availability of nutrients is one of the most important factors affecting yield and grain quality. Besides mineral nitrogen, nutrients include the following microelements: copper, manganese and zinc. They perform important functions in plant metabolic processes, and their deficiencies disrupt biochemical processes.

The aim of this study was to determine the crop yield, the content of mineral nutrients $(\mathrm{Cu}, \mathrm{Zn}, \mathrm{Mn}, \mathrm{Fe})$, protein and its composition in the grain of the spelt variety 'Schwabenkorn' as affected by the foliar application of micronutrients.

\section{Materials and methods}

A field experiment was carried out during 2011 2013 at the Research Station in Tomaszkowo $\left(53^{\circ} 72 \mathrm{~N}\right.$, $20^{\circ} 42 \mathrm{E}$ ), Poland. The experiment was set up using the random block method in three replications, on brown soil with the texture of light soil, Haplic Cambisol according to World Reference Base (WRB, 2014). The physical and chemical soil properties are presented in Table 1.
Table 1. Physical and chemical soil properties before the experiment (2011)

\begin{tabular}{|c|c|}
\hline Measured parameters & Values \\
\hline Soil type & Haplic Cambisol \\
\hline Soil texture & loam \\
\hline $\mathrm{pH}$ in $\mathrm{KCl}$ & 5.99 \\
\hline Total organic $\mathrm{C} \mathrm{g} \mathrm{kg}^{-1} \mathrm{DM}$ & 9.98 \\
\hline Total $\mathrm{N} \mathrm{g} \mathrm{kg}{ }^{-1} \mathrm{DM}$ & 0.95 \\
\hline P mg kg-1 DM & 35.5 \\
\hline $\mathrm{K} \mathrm{mg} \mathrm{kg}^{-1} \mathrm{DM}$ & 26.51 \\
\hline $\mathrm{Mg} \mathrm{mg} \mathrm{kg}^{-1} \mathrm{DM}$ & 7.5 \\
\hline $\mathrm{Mn} \mathrm{mg} \mathrm{kg}{ }^{-1} \mathrm{DM}$ & 192 \\
\hline $\mathrm{Cu} \mathrm{mg} \mathrm{kg}{ }^{-1} \mathrm{DM}$ & 2.3 \\
\hline $\mathrm{Zn} \mathrm{mg} \mathrm{kg}^{-1} \mathrm{DM}$ & 7.8 \\
\hline Fe mg kg-1 DM & 1500 \\
\hline
\end{tabular}

$\mathrm{DM}$ - dry matter

Nitrogen $(\mathrm{N})$ was applied to all the plots at a dose of $90 \mathrm{~kg} \mathrm{ha}^{-1}$, the amount was divided as follows: soil-applied $54 \mathrm{~kg} \mathrm{ha}^{-1} \mathrm{~N}$ (46\% urea) during the tillering stage (BBCH 21-22) and foliar-applied $36 \mathrm{~kg} \mathrm{ha}^{-1} \mathrm{~N}-$ (10\% urea solution) during the stem elongation stage (BBCH 30-31); triple superphosphate (46\%) at a dose of $30.2 \mathrm{~kg} \mathrm{ha}^{-1} \mathrm{P}$, and potassium salt $(56 \%)$ at a dose of 83.1 $\mathrm{kg} \mathrm{ha}^{-1} \mathrm{~K}$, before sowing. The fertilisation treatments of the experiment are presented in Table 2.

Table 2. Scheme of the field experiment

\begin{tabular}{ccc}
\hline Fertilisation treatments* & $\begin{array}{c}\text { Micronutrients** } \\
\mathrm{kg} \mathrm{ha}{ }^{-1}\end{array}$ & Form of micronutrients \\
\hline Control $(\mathrm{NPK})$ & - & $1.0 \%$ solution of $\mathrm{CuSO} \times 5 \mathrm{H}_{2} \mathrm{O}$ \\
$\mathrm{NPK}+\mathrm{Cu}$ & $\mathrm{Cu}(0.2)$ & $1.0 \%$ solution of $\mathrm{ZnSO}_{4} \times 7 \mathrm{H}_{2} \mathrm{O}$ \\
$\mathrm{NPK}+\mathrm{Zn}$ & $\mathrm{Zn}(0.2)$ & $0.5 \%$ solution of $\mathrm{MnSO}_{4} \times 5 \mathrm{H}_{2} \mathrm{O}$ \\
$\mathrm{NPK}+\mathrm{Mn}$ & $\mathrm{Mn}(0.2)$ & $1.0 \%$ solution of $\mathrm{CuSO}_{4} \times 5 \mathrm{H}_{2} \mathrm{O}$ \\
$\mathrm{NPK}+\mathrm{Cu}+\mathrm{Zn}+\mathrm{Mn}$ & $\mathrm{Cu}(0.2)$ & $1.0 \%$ solution of $\mathrm{ZnSO}_{4} \times 7 \mathrm{H}_{2} \mathrm{O}$ \\
& $\mathrm{Zn}(0.2)$ & $0.5 \%$ solution of $\mathrm{MnSO}_{4} \times 5 \mathrm{H}_{2} \mathrm{O}$ \\
\hline
\end{tabular}

Note. ${ }^{*}$ - in all treatments the same mineral NPK fertilisation $\left(90 \mathrm{~kg} \mathrm{ha}^{-1} \mathrm{~N}, 30.2 \mathrm{~kg} \mathrm{ha}^{-1} \mathrm{P}\right.$ and $\left.83.1 \mathrm{~kg} \mathrm{ha}^{-1} \mathrm{~K}\right)$ was used; ** micronutrients were foliar-applied at the stem elongation stage (BBCH 30-31).

The plot size was $6.25 \mathrm{~m}^{2}$, the harvested plot area was $4.0 \mathrm{~m}^{2}$, and winter triticale was a forecrop. Winter spelt variety 'Schwabenkorn' was sown at 5.50 million grains ha $^{-1}$, spacing between plant rows of $120 \mathrm{~mm}$. Agrotechnical practices, included shallow ploughing, were performed as soon as the forecrop was harvested. Ploughing before sowing and harrowing was performed in order to bury crop residue before winter wheat sowing. A cultivating-sowing unit was used immediately before sowing in all treatments in order to mix fertilisers (mineral) and prepare the soil for sowing. Weeds were eliminated with herbicides: in 2011 - Mustang Forte $195 \mathrm{SE}$ (a.i. florasulam $5 \mathrm{~g} \mathrm{dm}^{-3}$, aminopyralid $10 \mathrm{~g} \mathrm{dm}^{-3}$, 2.4 D $\left.180 \mathrm{~g} \mathrm{dm}^{-3}\right) 1.0 \mathrm{dm}^{-3} \mathrm{ha}^{-1}$ and Puma Universal 069 WG (a.i. fenoksaprop-P-etyl $69 \mathrm{~g} \mathrm{dm}^{-3}$ ) $1.2 \mathrm{dm}^{-3} \mathrm{ha}^{-1}$; in 2012 - Atlantis 12 OD (a.i. jodosulfuron methyl sodium $2 \mathrm{~g} \mathrm{dm}^{-3}$, mesosulfuron methyl $10 \mathrm{~g} \mathrm{dm}^{-3}$ ) $0.45 \mathrm{dm}^{-3} \mathrm{ha}^{-1}+$ Sekator $125 \mathrm{OD}$ (a.i. jodosulfuron methyl sodium $25 \mathrm{~g} \mathrm{dm}^{-3}$, amidosulfuron $\left.100 \mathrm{~g} \mathrm{dm}^{-3}\right) 0.15 \mathrm{dm}^{-3} \mathrm{ha}^{-1}$, in spring after resumption of wheat vegetation (BBCH 21-29). No protection was provided against pests and diseases.

The weather conditions during the years of the study are shown in Table 3. In the experimental years, the precipitation during spelt sowing and germination was higher in September of the first year (2011) - by 21.8 and $10.6 \mathrm{~mm}$ compared to the multi-year average. October and November 2011 were characterized by much lower precipitation than the following year (by 39.0 and $31.1 \mathrm{~mm}$ ) and also lower than the multi-year average (by 13.1 and $30.7 \mathrm{~mm}$ ). In the experimental years, the monthly precipitation in December was lower, and in January it was higher than the multi-year average values. In March 2012 and 2013, the precipitation was lower than multi-year average values - by 8.8 and $14.8 \mathrm{~mm}$. At the beginning of the vegetation period (April) in 2012, 
the precipitation $(73.1 \mathrm{~mm})$ was more than double the average rainfall sums of the multi-year average. In the experimental years (2011-2013), in May (beginning of coming into ear), the rainfall sums were much the same (51.7 and $54.5 \mathrm{~mm}$ ). In June 2012 (end of the tillering phase), the rainfall was $40 \%$ higher than in 2013 . In July (grain ripening stage), the precipitation in individual years was similar, although it considerably exceeded the multi-year average values ( $39 \%$ on average).

Table 3. Weather conditions in 2011-2013 and the multi-annual average of 1981-2010

\begin{tabular}{|c|c|c|c|c|c|c|c|c|c|c|c|c|c|}
\hline \multirow[b]{2}{*}{ Year } & \multicolumn{13}{|c|}{ Month } \\
\hline & 09 & 10 & 11 & 12 & 01 & 02 & 03 & 04 & 05 & 06 & 07 & 08 & $\begin{array}{c}\text { September- } \\
\text { August }\end{array}$ \\
\hline \multicolumn{13}{|c|}{ Temperature ${ }^{\circ} \mathrm{C}$} & average \\
\hline 2011-2012 & 14.1 & 8.3 & 3.1 & 2.3 & -1.7 & -7.5 & 3.0 & 7.8 & 13.4 & 15.0 & 19.0 & 17.7 & 7.9 \\
\hline 2012-2013 & 13.5 & 7.4 & 4.9 & -3.5 & -4.6 & -1.1 & -3.5 & 5.9 & 14.8 & 17.5 & 18.0 & 17.4 & 7.2 \\
\hline 1981-2010 & 12.8 & 8.0 & 2.9 & -0.9 & -2.4 & -1.7 & 1.8 & 7.7 & 13.5 & 16.1 & 18.7 & 17.9 & 7.9 \\
\hline \multicolumn{13}{|c|}{ Rainfall $\mathrm{mm}$} & sum \\
\hline 2011-2012 & 67.5 & 29.5 & 14.1 & 25.8 & 61.8 & 27.7 & 24.1 & 73.1 & 51.7 & 103.2 & 121.0 & 45.1 & 644.6 \\
\hline $2012-2013$ & 45.7 & 68.5 & 45.2 & 11.8 & 44.1 & 22.6 & 18.1 & 28.5 & 54.5 & 61.2 & 121.9 & 37.6 & 559.7 \\
\hline $1981-2010$ & 56.9 & 42.6 & 44.8 & 38.2 & 36.4 & 24.2 & 32.9 & 33.3 & 58.5 & 80.4 & 74.2 & 59.4 & 581.8 \\
\hline
\end{tabular}

Each year during the study period, the crop was harvested, ground and the samples were taken for chemical analysis. Spelt grain collected from the experimental field was first separated from spikes and was then dried and its yield was calculated in tonnes per hectare at $15 \%$ humidity. After grinding in a WŻ-1 type laboratory mill (Labortechnik, Germany), grain samples were subjected to hot mineralization in an $\mathrm{HNO}_{3}$ and $\mathrm{HClO}_{4}$ acid mixture (ratio $3: 1$ ). A sample of milled grain $(5 \mathrm{~g})$ was placed in a Kjeldahl flask and $30 \mathrm{ml}$ acid mixture was added. The next day it was heated in a digester heater K-439 (Buchi Speed Digester, Switzerland) until total sample transparency, $\mathrm{Cu}, \mathrm{Zn}, \mathrm{Mn}$ and $\mathrm{Fe}$ content was determined using an atomic absorption spectrometer-flame technique with an apparatus Hitachi Z-8200 (Japan). Total nitrogen was determined using the Kjeldahl method and converted to protein content $(\mathrm{N} \times 5.75)$. Quantitative and qualitative protein characteristics were determined through the RPHPLC technique developed by Wieser et al. (1998). Albumins plus globulins were twice extracted with $1 \mathrm{~mL}$ of $0.4 \mathrm{~mol} \mathrm{~L}^{-1}$ of $\mathrm{NaCl}$ with 0.067 of $\mathrm{mol} \mathrm{L}^{-1} \mathrm{HKNaPO}_{4}$ (pH 7.6); gliadins were extracted with $1 \mathrm{~mL}$ of $60 \%$ ethanol (three-fold extraction), and glutenins were twice extracted with $1 \mathrm{~mL}$ of $50 \%$ 1-propanol, $2 \mathrm{~mol} \mathrm{~L}^{-1}$ of urea, $0.05 \mathrm{~mol} \mathrm{~L}^{-1}$ of Tris-HCl (pH 7.5), 1\% DTT (ditiotreitol), under nitrogen. The determination was carried out using a 1050 series apparatus Hewlett Packard (Palo Alto, USA) with the following parameters: a RP-18 Vydac 218TP54 column with $5 \mu \mathrm{m}$ bead size and 300 A pore size, $250 \times 4.6 \mathrm{~mm}$; a Zorbax $300 \mathrm{SB}$ C18 pre-column, $4.6 \times 12.5 \mathrm{~mm}$; a column temperature of $45^{\circ} \mathrm{C}$, a mobile phase flow rate of $1 \mathrm{~mL} \mathrm{~min}^{-1}$, and an injection volume of $20 \mu \mathrm{L}$. A two-component gradient was used. Component A: $0 \min 75 \%, 5 \min 65 \%, 10 \min 50 \%, 17 \min 25 \%$, $18 \mathrm{~min} 15 \%$ and $19 \mathrm{~min} 75 \%$. The first component (A) was water with $0.1 \%$ of trifluoroacetic acid (TFA) and the second (B) was acetonitrile (ACN) with $0.1 \%$ of TFA. The absorbance spectra of eluted proteins were determined by a diode-array detector HP 1050 (Palo Alto, USA). Quantification of proteins was done by UV absorbance at $210 \mathrm{~nm}$. The integration procedure was performed using software HPLC $3 D$ ChemStation. The identification of gliadins was based on the second derivative of their UV spectra (Dziuba et al., 2007). Spectral parameters of individual peaks were compared using the ratio of tryptophan to tyrosine calculated using the protein sequence database Swiss-Prot/TrEMBL (http://www.expasy.org). The iden-tification of glutenin was performed using standards of high molecular weight (HMW) and low molecular weight (LMW) subunits isolated according to Wieser et al. (1998). A quantitative analysis of all protein fractions was carried out, based on a curve for a gliadin standard prepared on an intralaboratory basis. The results were expressed in mAUs (milli-absorbance units). One-factor analysis of variance was used in statistical calculations, which was consistent with the mathematical model of the experiment configuration - the randomized blocks. Besides basic statistical parameters, the researchers determined statistically homogeneous groups using the Duncan's test, at a significance level of $\alpha=0.05$. Moreover, they formulated correlation dependencies between the content of micronutrients in grain and grain yield, protein content and its fraction composition. A spread sheet Excel and statistical package Statistica 10.0 were used to perform statistical computations and analyses.

\section{Results and discussion}

Grain yield of spelt (Triticum aestivum spp. spelta L.) variety 'Schwabenkorn' with the foliar application of $\mathrm{Cu}, \mathrm{Zn}$ and $\mathrm{Mn}$, individually or in combination, ranged from 5.63 to $5.98 \mathrm{t} \mathrm{ha}^{-1}$ (Table 4). This yield level was much like that obtained by Lacko-Bartošová et al. (2010). According to them, the average grain yield for the variety 'Schwabenkorn' was $5.54 \mathrm{t} \mathrm{ha}^{-1}$. Andruszczak et al. (2011) observed that levels of crop chemicalization and rates of mineral fertilisation diversified the level of grain yield of variety 'Schwabenkorn'. In the current research, it was found that supplementing mineral fertilisation with micronutrients did not have a significant effect on the 
Table 4. Grain yield, content of micronutrients in the grain of spelt variety 'Schwabenkorn' foliar-applied with micronutrients

\begin{tabular}{|c|c|c|c|c|c|c|}
\hline \multirow{2}{*}{\multicolumn{2}{|c|}{ Fertilisation treatments }} & \multirow{2}{*}{$\begin{array}{c}\text { Grain yield } \\
\mathrm{t} \mathrm{ha}^{-1}\end{array}$} & $\mathrm{Cu}$ & $\mathrm{Fe}$ & $\mathrm{Zn}$ & $\mathrm{Mn}$ \\
\hline & & & \multicolumn{4}{|c|}{$\mathrm{mg} \mathrm{kg}^{-1}$} \\
\hline \multirow{2}{*}{ Control (NPK) } & average & $5.47 \mathrm{a}$ & $3.65 \mathrm{a}$ & $58.1 \mathrm{~d}$ & $33.4 \mathrm{c}$ & $41.8 \mathrm{~d}$ \\
\hline & SD & 0.379 & 0.111 & 1.652 & 0.216 & 0.726 \\
\hline \multirow{2}{*}{$\mathrm{NPK}+\mathrm{Cu}$} & average & $5.98 \mathrm{a}$ & $3.37 \mathrm{~b}$ & $59.0 \mathrm{~d}$ & $30.5 \mathrm{~d}$ & $46.4 \mathrm{a}$ \\
\hline & $\mathrm{SD}$ & 0.463 & 0.038 & 0.650 & 0.606 & 0.450 \\
\hline \multirow{2}{*}{$\mathrm{NPK}+\mathrm{Zn}$} & average & $5.63 \mathrm{a}$ & $3.71 \mathrm{a}$ & $70.5 \mathrm{a}$ & $40.5 \mathrm{a}$ & $40.4 \mathrm{e}$ \\
\hline & $\mathrm{SD}$ & 0.607 & 0.068 & 1.500 & 1.185 & 0.879 \\
\hline \multirow{2}{*}{$\mathrm{NPK}+\mathrm{Mn}$} & average & $5.73 \mathrm{a}$ & $3.26 \mathrm{~b}$ & $62.3 \mathrm{c}$ & $35.1 \mathrm{~b}$ & $45.1 \mathrm{~b}$ \\
\hline & SD & 0.608 & 0.060 & 0.656 & 0.333 & 1.076 \\
\hline \multirow{2}{*}{$\mathrm{NPK}+\mathrm{Cu}+\mathrm{Zn}+\mathrm{Mn}$} & average & $5.88 \mathrm{a}$ & $3.04 \mathrm{c}$ & $64.5 \mathrm{~b}$ & $35.8 \mathrm{~b}$ & $43.0 \mathrm{c}$ \\
\hline & SD & 0.564 & 0.078 & 1.214 & 0.823 & 0.879 \\
\hline & & & Years & & & \\
\hline \multirow{2}{*}{2012} & average & $4.00 \mathrm{~b}$ & $3.40 \mathrm{a}$ & $63.7 \mathrm{a}$ & $33.7 \mathrm{~b}$ & $42.9 \mathrm{~b}$ \\
\hline & SD & 0.729 & 0.380 & 4.232 & 4.484 & 3.292 \\
\hline \multirow{2}{*}{2013} & average & $7.47 \mathrm{a}$ & $3.41 \mathrm{a}$ & $62.1 \mathrm{~b}$ & $36.5 \mathrm{a}$ & $43.8 \mathrm{a}$ \\
\hline & SD & 0.400 & 0.055 & 3.561 & 1.655 & 2.522 \\
\hline
\end{tabular}

Note. Averages in columns (separately for micronutrients and years) followed by the same letter are insignificant $(\alpha<0.05)$; SD standard deviation.

grain yield. A significantly higher (by $86.8 \%$ ) grain yield was obtained in the second experimental year. This may have been caused by the different thermal conditions in the winter of 2012-2013 which helped the plants to pass through the stage of vernalisation.

Application of mineral fertilisers with micronutrients results in a higher yield and content of mineral components in grain (Narimani et al., 2010; Nadim et al., 2012). The nutritive value of spelt grain is high - the grain contains all necessary nutrients (Rachon, Szumiło, 2009; Rachoń et al., 2015). Those authors found that, regardless of the micronutrients applied, the grain of spelt variety 'Schwabenkorn' contained more $\mathrm{Cu}, \mathrm{Mn}$ and Fe compared to the finding of Kraska et al. (2013). The research carried out by Gomez-Becerra et al. (2010) and Kohajdová and Karovičová (2009) showed a higher content of $\mathrm{Zn}$ in spelt grain than in the current experiment (70 and $47 \mathrm{~g} \mathrm{~kg}^{-1}$, respectively), while Fe concentration was lower (57-60 $\mathrm{g} \mathrm{kg}^{-1}$ ). Kraska et al. (2013) observed a strong dependence of micronutrient content in grain on the variety. Among eight spelt varieties evaluated by them, the variety 'Schwabenkorn' was richest in iron.

Supplementation of the basic mineral fertilisation NPK with $\mathrm{Cu}, \mathrm{Mn}$ and micronutrients in combination $(\mathrm{Cu}+\mathrm{Zn}+\mathrm{Mn})$ reduced $\mathrm{Cu}$ content in grain - by 7.7 , 10.7 and $16.7 \%$, respectively. A statistically significant increase in iron concentration in grain partly resulted from a higher supply of $\mathrm{Zn}$ (by 21.3\%), Mn (by 7.2\%) and micronutrients $(\mathrm{Cu}+\mathrm{Zn}+\mathrm{Mn})$ application (by $11.0 \%)$. Zinc content in grain increased by $21.3 \%$ after spraying (at the stem elongation stage) with a urea solution and $\mathrm{ZnSO}_{4} \times 7 \mathrm{H}_{2} \mathrm{O}$, and after treatment with $\mathrm{MnSO}_{4} \times 5 \mathrm{H}_{2} \mathrm{O}-$ by $5.1 \%$. The application of micronutrients with mineral fertilisers increased $\mathrm{Zn}$ content by $7.2 \%$. Adding $\mathrm{Cu}$ to NPK fertiliser reduced Zn content by $8.7 \%$.

The application of nitrogen as urea, together with $\mathrm{Cu}$ or $\mathrm{Mn}$, or in combination with all the micronutrients $(\mathrm{Cu}+\mathrm{Zn}+\mathrm{Mn})$ increased $\mathrm{Mn}$ content by 11.0, 7.9 and $2.9 \%$, respectively. Foliar application of a $10 \%$ urea solution with $\mathrm{Zn}$ significantly reduced $\mathrm{Mn}$ content. In the second experimental year, $\mathrm{Zn}$ and $\mathrm{Mn}$ content increased by $8.3 \%$ and $2.1 \%$, respectively, and iron content dropped by $2.5 \%$. Lack of a clear effect of foliar application of microelements on the chemical composition of spelt grain may result from an ionic antagonism present in the plant.

Spelt grain is characterized by higher protein content than bread wheat grain (Kohajdová, Karovičová, 2008; Rachoń, Szumiło, 2009; Escarnot et al., 2012). According to Mikos and Podolska (2012) and Świeca et al. (2014), total protein content in spelt variety 'Schwabenkorn' grain varies within a wide range from $13.2 \%$ to $15.5 \%$. High protein content in grain of that variety was observed in the research carried out by LackoBartošová and Rédlová (2007) - 18.6\%. According to Rachon et al. (2015), the higher nitrogen fertilisation rate $\left(140 \mathrm{~kg} \mathrm{ha}^{-1} \mathrm{~N}\right.$ compared to $\left.70 \mathrm{~kg} \mathrm{ha}^{-1} \mathrm{~N}\right)$ resulted in increased protein (by 1.6 percentage points). The tested fertilisation treatments had an ambiguous influence on the protein content levels reached (Table 5). Supplementing the basic fertilisation with micronutrients, applied either individually ( $\mathrm{Zn}$ and $\mathrm{Mn})$ or in combination $(\mathrm{Cu}+\mathrm{Zn}+$ $\mathrm{Mn})$ reduced the protein content in grain.

According to Schober et al. (2006), European spelt varieties were characterized by much the same protein content, less insoluble polymeric protein and more gliadins and soluble polymeric proteins compared to American varieties. Escarnot et al. (2012) indicate that, compared to bread wheat, spelt grain is characterized by a similar content of albumin and globulin fractions and higher content of gliadin fractions compared to glutenins. The gliadins:glutenins ratio is 3.5 (for spelt) and 2.0 (for common wheat), respectively. According to PruskaKędzior et al. (2008), among all cereal species under assessment grain spelt was the most valuable in term of its technological properties.

The protein fraction content in spelt grain differed depending on the applied micronutrients (Table 5). The highest albumin and globulin content (19987 mAUs) was observed after applying NPK with $0.2 \mathrm{~kg} \mathrm{ha}^{-1} \mathrm{Cu}(7.7 \%$ rise compared to mineral NPK fertilisation). 
Table 5. The content and composition of proteins in the grain of spelt variety 'Schwabenkorn' foliar-applied with micronutrients

\begin{tabular}{|c|c|c|c|c|c|c|}
\hline \multicolumn{2}{|c|}{ Fertilisation treatments } & \multirow{2}{*}{$\begin{array}{c}\text { Content of } \\
\text { protein } \\
\%\end{array}$} & $\begin{array}{c}\text { Albumins and } \\
\text { globulins }\end{array}$ & Gliadins & Glutenins & \multirow[t]{2}{*}{ Gliadins:glutenins } \\
\hline & & & & mAUs & & \\
\hline \multirow{2}{*}{ Control (NPK) } & average & $13.4 \mathrm{a}$ & $18554 \mathrm{~b}$ & $45878 \mathrm{~b}$ & $41849 \mathrm{c}$ & $1.10 \mathrm{~b}$ \\
\hline & SD & 0.058 & 20.0 & 150.0 & 211.9 & 0.006 \\
\hline \multirow{2}{*}{$\mathrm{NPK}+\mathrm{Cu}$} & average & $13.5 \mathrm{a}$ & $19987 \mathrm{a}$ & $44704 \mathrm{~b}$ & $42755 \mathrm{bc}$ & $1.05 \mathrm{c}$ \\
\hline & $\mathrm{SD}$ & 0.144 & 123.4 & 285.6 & 163.4 & 0.006 \\
\hline \multirow{2}{*}{$\mathrm{NPK}+\mathrm{Zn}$} & average & $12.4 \mathrm{c}$ & $18328 \mathrm{~b}$ & $42052 \mathrm{c}$ & $43321 \mathrm{ab}$ & $0.97 \mathrm{e}$ \\
\hline & $\mathrm{SD}$ & 0.029 & 195.1 & 154.9 & 365.8 & 0.009 \\
\hline \multirow{2}{*}{$\mathrm{NPK}+\mathrm{Mn}$} & average & $13.1 \mathrm{~b}$ & $18432 \mathrm{~b}$ & $48530 \mathrm{a}$ & $38117 \mathrm{~d}$ & $1.27 \mathrm{a}$ \\
\hline & $\mathrm{SD}$ & 0.289 & 37.5 & 385.1 & 140.3 & 0.014 \\
\hline \multirow{2}{*}{$\mathrm{NPK}+\mathrm{Cu}+\mathrm{Zn}+\mathrm{Mn}$} & average & $13.0 \mathrm{~b}$ & $18216 \mathrm{~b}$ & $43320 \mathrm{c}$ & $44257 \mathrm{a}$ & $0.98 \mathrm{~d}$ \\
\hline & SD & 0.116 & 26.5 & 117.7 & 281.4 & 0.004 \\
\hline \multicolumn{7}{|c|}{ Years } \\
\hline \multirow{2}{*}{2012} & average & $13.4 \mathrm{a}$ & $19570 \mathrm{a}$ & $43341 \mathrm{~b}$ & $45870 \mathrm{a}$ & $0.94 \mathrm{~b}$ \\
\hline & $\mathrm{SD}$ & 0.468 & 68.3 & 231.1 & 220.0 & 0.003 \\
\hline \multirow{2}{*}{2013} & average & $12.8 \mathrm{a}$ & $17836 \mathrm{~b}$ & $46453 \mathrm{a}$ & $38250 \mathrm{~b}$ & $1.32 \mathrm{a}$ \\
\hline & SD & 0.123 & 98.3 & 401.0 & 303.1 & 0.005 \\
\hline
\end{tabular}

Note. Averages in columns (separately for micronutrients and years) followed by the same letter are insignificant $(\alpha<0.05)$; SD standard deviation; mAUs - milli-absorbance units.

In general protein share, storage proteins (gliadins and glutenins) significantly prevail (from $81.4 \%$ to $82.8 \%$ ) over enzymatic and structural proteins (albumins and globulins). This was confirmed in the research carried out by Świeca et al. (2014), where storage proteins constituted $71 \%$ to $72 \%$ in the grain of spelt variety 'Schwabenkorn'. The gliadins:glutenins ratio ranged from 0.97 to 1.27 , and fertiliser treatments also significantly differentiated it. Adding Mn to mineral fertilisers caused the highest accumulation of gliadins (48530) and a considerable reduction of glutenins (38117). This resulted in an increased ratio (1.27). According to Konopka et al. (2007), a high gliadins:glutenins ratio may indicate deterioration of protein technological properties. A higher gliadin share proves the potential predominance of protein sticky properties over its elastic properties. In the completed research, mineral fertilisation, including foliar spraying with $\mathrm{Zn}$ applied individualy and in combination $(\mathrm{Cu}+\mathrm{Zn}+\mathrm{Mn})$, resulted in reduced content of gliadins and increased content of glutenins, while their advisable ratio ( 0.97 and 0.98$)$ was maintained. Statistical analysis confirmed the impact of the experimental years on protein content and composition. In the first year of the study, the researchers observed higher content of albumins, globulins and glutenins, while the content of gliadins was lower.

Foliar application of nitrogen in combination with $\mathrm{Cu}, \mathrm{Zn}$ and $\mathrm{Mn}$, either individually or in combination differentiated the content of monomeric gliadins and polymeric glutenins (Table 6). Spraying with $\mathrm{MnSO}_{4} \times$ $5 \mathrm{H}_{2} \mathrm{O}$ caused an increase in the content of gliadins $-\omega$, $\alpha / \beta$ and $\gamma$, by $8.0,6.0$ and $5.3 \%$, respectively, compared to the treatment without micronutrient fertilisation. Foliar application of $\mathrm{Cu}$ significantly reduced the accumulation of $\omega$ and $\alpha / \beta$ gliadins (by $6.4 \%$ and $5.7 \%$ ), and $\mathrm{Zn}$ reduced $\alpha / \beta$ and $\gamma$ gliadins (by $6.1 \%$ and $11.8 \%$ ).

Table 6. The protein fractions of gliadins and glutenins in the grain of spelt variety 'Schwabenkorn' foliar-applied with micronutrients

\begin{tabular}{ccccccc}
\hline \multirow{2}{*}{ Fertilisation treatments } & \multicolumn{3}{c}{ Gliadins (mAUs) } & \multicolumn{2}{c}{ Glutenins (mAUs) } \\
\cline { 2 - 7 } & & $\omega$ & $\alpha / \beta$ & $\gamma$ & HMW & LMW \\
\hline \multirow{2}{*}{ Control (NPK) } & average & $1895 \mathrm{~b}$ & $25426 \mathrm{~b}$ & $18557 \mathrm{~b}$ & $11399 \mathrm{~b}$ & $30451 \mathrm{~b}$ \\
& $\mathrm{SD}$ & 9.29 & 124.86 & 23.64 & 66.34 & 219.91 \\
\hline \multirow{2}{*}{$\mathrm{NPK}+\mathrm{Cu}$} & average & $1774 \mathrm{c}$ & $23967 \mathrm{c}$ & $18964 \mathrm{ab}$ & $11303 \mathrm{~b}$ & $31452 \mathrm{ab}$ \\
& $\mathrm{SD}$ & 15.51 & 62.17 & 211.14 & 42.58 & 170.50 \\
\hline \multirow{2}{*}{$\mathrm{NPK}+\mathrm{Zn}$} & average & $1815 \mathrm{bc}$ & $23864 \mathrm{c}$ & $16374 \mathrm{c}$ & $11988 \mathrm{a}$ & $31333 \mathrm{ab}$ \\
& $\mathrm{SD}$ & 32.53 & 209.10 & 70.47 & 51.74 & 380.31 \\
\hline \multirow{2}{*}{$\mathrm{NPK}+\mathrm{Mn}$} & average & $2047 \mathrm{a}$ & $26944 \mathrm{a}$ & $19539 \mathrm{a}$ & $11213 \mathrm{~b}$ & $26904 \mathrm{c}$ \\
& $\mathrm{SD}$ & 38.37 & 301.80 & 191.42 & 201.55 & 64.30 \\
\hline \multirow{2}{*}{$\mathrm{NPK}+\mathrm{Cu}+\mathrm{Zn}+\mathrm{Mn}$} & average & $1872 \mathrm{bc}$ & $24742 \mathrm{~b}$ & $16707 \mathrm{c}$ & $12062 \mathrm{a}$ & $32195 \mathrm{a}$ \\
& SD & 30.01 & 62.75 & 28.68 & 28.68 & 261.37 \\
\hline \multirow{2}{*}{2012} & & & Years & & $11546 \mathrm{a}$ & $32345 \mathrm{a}$ \\
& average & $1672 \mathrm{~b}$ & $22446 \mathrm{~b}$ & $19249 \mathrm{a}$ & 155.45 & 301.50 \\
\hline \multirow{2}{*}{2013} & SD & 66.07 & 285.25 & 78.11 & $11640 \mathrm{a}$ & $28589 \mathrm{~b}$ \\
& average & $2089 \mathrm{a}$ & $27532 \mathrm{a}$ & $16807 \mathrm{~b}$ & 58.12 & 77.52 \\
\hline
\end{tabular}

Note. Averages in columns (separately for micronutrients and years) followed by the same letter are insignificant $(\alpha<0.05)$; SD standard deviation; mAUs - milli-absorbance units; HMW - high molecular weight, LMW - low molecular weight. 
As a result of spraying with micronutrients $(\mathrm{Cu}+$ $\mathrm{Zn}+\mathrm{Mn})$, the $\gamma$ gliadin content dropped by $10 \%$ compared to NPK. Glutenin content levels (HMW and LMW) in spelt grain are primarily genetically conditioned (Wieser et al., 2009) and are differentiated by weather conditions and both mineral and organic fertilisation (Stępień, Wojtkowiak, 2013). In the completed research, the highest content of HMW glutenins (12062 mAUs) and LMW (32195 mAUs) was observed in the case of application of three micronutrients with nitrogen, as compared to mineral nitrogen fertilisation. As a result of fertilisation with $\mathrm{Zn}$, HMW glutenins increased by $5.2 \%$. Adding Mn to mineral fertilisation reduced the concentration of LMW glutenins by $11.6 \%$. The content of $\omega$ and $\alpha / \beta$ gliadins was found to increase and that of $\gamma$ gliadins and LMW glutenins was found to decrease in grain during the second year of the study. Based on the findings of the study the changes in the content and composition of the protein resulting from application of microelements were not uniform. $\mathrm{Cu}, \mathrm{Zn}$ and $\mathrm{Mn}$ participate in many physiological processes vital for the plant. The difficulty in interpreting the effect of these microelements results from tha fact that it cannot be definitely stated which physiological effects evoked by these elements had an effect on the direction of the change. Weather conditions could also influence the quality of spelt grain during the vegetation period.

Correlation analysis proved a positive relationship between Mn content in grain and the volume of albumins and globulins $(r=0.647)$, the sum of gliadins $(r=0.524)$ and $\gamma$ gliadins $(r=0.695)$, and a negative relationship with the content of HMW glutenins $(r=-0589)$ (Table 7).

Table 7. Correlations between micronutrients, grain yield, content of protein, composition of protein in the grain of spelt variety 'Schwabenkorn' with the foliar application of micronutrients

\begin{tabular}{|c|c|c|c|c|c|}
\hline & & $\mathrm{Cu}$ & $\mathrm{Mn}$ & $\mathrm{Fe}$ & $\mathrm{Zn}$ \\
\hline \multicolumn{2}{|c|}{ Grain yield } & ns & ns & ns & ns \\
\hline \multicolumn{2}{|c|}{ Content of protein } & ns & ns & -0.659 & ns \\
\hline \multicolumn{2}{|c|}{ Albumins and globulins } & ns & 0.647 & ns & 0.739 \\
\hline \multicolumn{2}{|c|}{ Gliadins } & ns & 0.524 & -0.591 & ns \\
\hline \multicolumn{2}{|c|}{ Glutenins } & ns & $\mathrm{ns}$ & ns & ns \\
\hline \multicolumn{2}{|c|}{ Gliadins:glutenins } & ns & ns & ns & ns \\
\hline \multirow{3}{*}{ Gliadins } & $\omega$ & ns & ns & ns & ns \\
\hline & $\alpha / \beta$ & ns & ns & ns & ns \\
\hline & $\gamma$ & ns & 0.695 & 0.754 & 0.540 \\
\hline \multirow{2}{*}{ Glutenins } & HMW & ns & -0.589 & 0.720 & ns \\
\hline & LMW & ns & $\mathrm{ns}$ & $\mathrm{ns}$ & $\mathrm{ns}$ \\
\hline
\end{tabular}

ns - not significant differences; HMW - high molecular weight, LMW - low molecular weight

A positive correlation was also observed between Fe content and $\gamma$ gliadins $(r=0.754)$ and HMW glutenins $(r=0.720)$, and a negative correlation with sum of gliadins. $\mathrm{Zn}$ content in grain was positively correlated with the amount of albumins and globulins $(r=0.739)$ and $\gamma$ gliadins $(r=0.540)$.

\section{Conclusions}

1. Supplementing NPK fertilisation with $\mathrm{Mn}$ and micronutrients used in combination $(\mathrm{Cu}+\mathrm{Zn}+$ $\mathrm{Mn}$ ) increased $\mathrm{Fe}, \mathrm{Zn}$ and $\mathrm{Mn}$ content in spelt grain. Fertilisation with $\mathrm{Zn}$ increased $\mathrm{Fe}$ and $\mathrm{Zn}$ contents, and fertilisation with $\mathrm{Cu}$ increased the amount of $\mathrm{Mn}$ in grain.

2. Additional fertilisation with copper, zinc and micronutrients in combination had a positive impact on the gliadins:glutenins ratio.

3. As a result of foliar fertilisation with $\mathrm{Mn}$, the content of $\omega, \alpha / \beta, \gamma$ gliadins increased, and the content of low molecular weight (LMW) glutenins dropped. Foliar spraying with $\mathrm{Cu}$ decreased the content of $\alpha / \beta$ and $\omega$ gliadins in grain. Fertilisation with $\mathrm{Zn}$ reduced $\alpha / \beta$ content and increased the amount of high molecular weight (HMW) glutenin fractions. The application of micronutrients in combination $(\mathrm{Cu}+\mathrm{Zn}+\mathrm{Mn})$ reduced the content of $\gamma$ gliadins and increased the HMW and LMW glutenins content.

Received 09042015 Accepted 28082015

\section{References}

Akeret Ö. 2005. Plant remains from a Bell Beaker site in Switzerland, and the beginnings of Triticum spelta (spelt) cultivation in Europe. Vegetation History and Archaeobotany, 14: 279-286 http://dx.doi.org/10.1007/s00334-005-0071-1

Andruszczak S., Kwiecińska-Poppe E., Kraska P., Pałys E. 2011. Yield of winter cultivars of spelt wheat (Triticum aestivum ssp. spelta L.) cultivated under diversified conditions of mineral fertilization and chemical protection. Acta Scientiarium Polonorum, seria Agricultura, 10 (4): $5-14$

Branković G., Dragičević V., Dodig D., Knežević D., Kobiljski B., Šurlan-Momirović G. 2015. Albumin content in bread wheat (Triticum aestivum L.) and durum wheat (Triticum durum Desf.) as affected by the environment. Zemdirbyste-Agriculture, 102 (3): 281-288 http://dx.doi.org/10.13080/z-a.2015.102.036

Cazzato E., Tufarelli V., Laudadio V., Stellacci A. M., Selvaggi M., Leoni B., Troccoli C. 2013. Forage yield and quality of emmer (Triticum dicoccum Schübler) and spelt (Triticum spelta L.) as affected by harvest period and nitrogen fertilization. Acta Agriculturae Scandinavica, Section B: Soil and Plant Science, 63 (7): 571-578 http://dx.doi.org/10.1080/09064710.2013.828097

Dziuba J., Nałęcz D., Minkiewicz P., Hanasiewicz A. 2007. Application of ultraviolet spectroscopy to discriminate wheat $\alpha / \beta$ and $\gamma$-gliadins separated using high-performance liquid chromatography - a short report. Polish Journal of Food and Nutrition Sciences, 57 (2): 191-193

Escarnot E., Jacquemin J. M., Agneessens R., Paquot M. 2012. Comparative study of the content and profiles of macronutrients in spelt and wheat, a review. Biotechnologie. Agronomie Société et Environnement, 16 (2): 243-256 
Goesaert H., Brijs K., Veraverbeke W. S., Courtin C. M., Gebruers K., Delcour J. A. 2005. Wheat flour constituents: how they impact bread quality, and how to impact their functionality. Trends in Food Science and Technology, 16 (1-3): 12-30

http://dx.doi.org/10.1016/j.tifs.2004.02.011

Gomez-Becerra H. F., Erdem H., Yazici A.,Tutus Y., Torun B., Ozturk L., Cakmak I. 2010. Grain concentrations of protein and mineral nutrients in a large collection of spelt wheat grown under different environments. Journal of Cereal Science, 52: 342-349 http://dx.doi.org/10.1016/j.jcs.2010.05.003

Kohajdová Z., Karovičová J. 2008. Nutritional value and baking applications of spelt wheat. Acta Scientiarum Polonorum. Technologia Alimentaria, 7 (3): 5-14

Kohajdová Z., Karovičová J. 2009. Chemical characteristics and pasting properties of commercial Slovak common and spelt wheat flours. Agriculturae Conspectus Scientificus, 74 (4): 313-317

Konopka I., Fornal Ł., Dziuba M., Czaplicki S., Nałęcz D. 2007. Composition of proteins in wheat grain obtained by sieve classification. Journal of the Science of Food and Agriculture, 87 (12): 2198-2206 http://dx.doi.org/10.1002/jsfa.2900

Kraska P., Andruszczak S., Kwiecińska-Poppe E., Pałys E. 2013. Effect of chemical crop protection on the content of some elements in grain of spelt wheat (Triticum aestivum ssp. spelta). Journal of Elementology, 18 (1): 79-90

Lacko-Bartošová M., Rédlová M. 2007. The significance of spelta wheat cultivated in ecological farming in the Slovak Republic. Proceeding of the Conference on Organic Farming, p. 79-81

Lacko-Bartošová M., Korczyk-Szabó J., Ražný R. 2010. Triticum spelta - a specialty grain for ecological farming systems. Research Journal of Agricultural Science, 42 (1): 143-147

Mikos M., Podolska G. 2012. Bread-making quality of old common bread (Triticum aestivum ssp. vulgare L.) and spelt (Triticum aestivum ssp. spelta L.) wheat cultivars. Journal of Food, Agriculture and Environment, 10 (3-4): 221-224

Nadim M. A., Awan I. U., Baloch M. S., Khan E. A., Naveed K., Khan M.A. 2012. Response of wheat (Triticum aestivum L.) to different micronutrients and their application methods. Journal of Animal and Plant Sciences, 22 (1): 113-119

Narimani H., Rahimi M. M., Ahmadikhah A., Vaezi B. 2010. Study on the effects of foliar spray of micronutrient on yield and yield components of durum wheat. Archives Applied Scientific Research, 2 (6): 168-176

Podolska G. 2008. The effect of Amistar fungicide on grain yield and protein compositions in winter wheat. ZemdirbysteAgriculture, 95 (3): 259-265

Pruska-Kędzior A., Kędzior Z., Klockiewicz-Kamińska E. 2008. Comparison of viscoelastic properties of gluten from spelt and common wheat. European Food Research and Technology, 227: 199-207 http://dx.doi.org/10.1007/s00217-007-0710-0
Rachoń L., Szumiło G. 2009. Comparison of chemical composition of selected winter wheat species. Journal of Elementology, 14 (1): 135-146 http://dx.doi.org/10.5601/jelem.2009.14.1.14

Rachoń L., Szumiło G., Brodowska M., Woźniak A. 2015. Nutritional value and mineral composition of grain of selected wheat species depending on the intensity of a production technology. Journal of Elementology, 20 (3): $705-715$

Ruibal-Mendieta N. L., Delacroix D. L., Mignolet E., Pycke J. M., Marques C., Rozenberg R., Petitjean G., Habib-Jiwan J. L., Meurens M. 2005. Spelt (Triticum aestivum ssp. spelta) as a source of breadmaking flours and bran naturally enriched in oleic acid and minerals but not phytic acid. Journal of Agricultural and Food Chemistry, 53: $2751-275$ http://dx.doi.org/10.1021/jf048506e

Schober T. J., Beana S. R., Kuhn M. 2006. Gluten proteins from spelt (Triticum aestivum ssp. spelta) cultivars: arheological and size-exclusion high-performance liquid chromatography study. Journal of Cereal Science, 44: 161-173 http://dx.doi.org/10.1016/j.jcs.2006.05.007

Stępień A., Wojtkowiak K. 2013. Composition of gluten proteins in spring and winter wheat grain cultivated under conditions of varied fertilization. Acta Agriculturae Scandinavica, Section B: Soil and Plant Science, 63 (7): 588-594 http://dx.doi.org/10.1080/09064710.2013.829866

Świeca M., Dziki D., Gawlik-Dziki U., Różyło R., Andruszczak S., Kraska P., Kowalczyk D., Pałys E., Baraniak B. 2014. Grinding and nutritional properties of six spelt (Triticum aestivum ssp. spelta L.) cultivars. Cereal Chemistry, 91 (3): 247-254 http://dx.doi.org/10.1094/CCHEM-02-13-0019-R

Wieser H., Antes S., Seilmeier W. 1998. Quantitative determination of gluten protein types in wheat flour by reversed phase high-performance liquid chromatography. Cereal Chemistry, 75: 644-650 http://dx.doi.org/10.1094/CCHEM.1998.75.5.644

Wieser H., Mueller K. J., Koehler P. 2009. Studies on the protein composition and baking quality of einkorn lines. European Food Research and Technology, 229: 523-532 http://dx.doi.org/10.1007/s00217-009-1081-5

WRB 2014. World reference base for soil resources 2014. International soil classification system for naming soils and creating legends for soil maps. World Soil Resources Reports No. 106. FAO, Rome 
ISSN 1392-3196 / e-ISSN 2335-8947

Zemdirbyste-Agriculture, vol. 102, No. 4 (2015), p. 389-396

DOI 10.13080/z-a.2015.102.049

\title{
Spelta (Triticum aestivum spp. spelta L.) kviečių maistinė vertė priklausomai nuo tręšimo per lapus variu, cinku ir magniu
}

\author{
K. Wojtkowiak, A. Stępień \\ Varmijos ir Mozūrų universitetas, Lenkija
}

\section{Santrauka}

Tyrimo metu veislès 'Schwabenkorn' spelta kviečių grūduose buvo nustatytas grūdų derlius, mineralinių medžiagų $(\mathrm{Cu}, \mathrm{Zn}, \mathrm{Mn}$ bei Fe) kiekis, baltymai ir jų sudètis, priklausomai nuo tręšimo mikroelementais per lapus. Lauko bandymas buvo vykdytas 2011-2013 m. Lenkijoje, Tomaszkowo bandymų stotyje (53॰72 N, $\left.20^{\circ} 42 \mathrm{E}\right)$. Mikroelementai $\mathrm{Cu}, \mathrm{Zn}$ ir Mn buvo naudojami kartu su mineralinėmis trąšomis $(\mathrm{Cu}+\mathrm{Zn}+\mathrm{Mn})$. Visi laukeliai buvo tręšti $90 \mathrm{~kg} \mathrm{ha}^{-1}$ azoto, trigubu superfosfatu - norma, atitinkančia $30,2 \mathrm{~kg} \mathrm{ha}^{-1} \mathrm{P}$, ir kalio druska - norma, atitinkančia $83,1 \mathrm{~kg} \mathrm{ha}^{-1} \mathrm{~K}$. Varis $\left(1,0 \%\right.$ tirpalas $\left.\mathrm{CuSO}_{4} \times 5 \mathrm{H}_{2} \mathrm{O}\right)$, cinkas $\left(1,0 \%\right.$ tirpalas $\left.\mathrm{ZnSO}_{4} \times 7 \mathrm{H}_{2} \mathrm{O}\right)$ ir manganas $(0,5 \%$ tirpalas $\mathrm{MnSO}_{4} \times 5 \mathrm{H}_{2} \mathrm{O}$ ) buvo purškiami ant lapų kaip vandeniniai tirpalai stiebo ilgejjimo tarpsniu. Mineralinis tręšimas, taip pat ir mikroelementais (atskirai arba kartu), grūduose pakeitė mineralinių maisto medžiagų bei baltymų kiekị ir jų atskirų frakcijų sudètị. Nustatyta, kad grūdai turejjo didelį kiekị Cu, Mn ir Fe. Tręšimas Mn, taip pat ir mikroelementais $(\mathrm{Cu}+\mathrm{Zn}+\mathrm{Mn})$, kaip priedas prie NPK tręšimo, spelta grūduose padidino Fe, $\mathrm{Zn}$ ir Mn kiekị. Tręšimas $\mathrm{Zn}$ grūduose padidino Fe ir Zn kiekį, o $\mathrm{Cu}$ - Mn kiekį. Bendras baltymų kiekis spelta grūduose svyravo nuo 12,4 iki 13,5 \%. Nustatyta, kad didžiausią dalị bendro baltymų kiekio sudaro atsarginiai baltymai. Papildomas tręšimas $\mathrm{Cu}$ ir Zn kartu su mikroelementais turejjo teigiamos įtakos gliadinų ir gluteninų santykiui. Tręšimas Mn per lapus padidino gliadinų $\omega, \alpha / \beta$ bei $\gamma$ kiekị ir sumažino mažo molekulinio svorio gluteninų kiekị. Tręšimas Cu per lapus sumažino gliadinų $\alpha / \beta$ ir $\omega$ kiekį. Tręšimas Zn sumažino gluteninų $\alpha / \beta$ kiekị ir padidino didelio molekulinio svorio gluteninų frakcijų kiekị. Tręšimas mikroelementų deriniu sumažino gliadino $\gamma$ ir padidino didelio bei mažo molekulinio svorio gluteninų kiekị. Auginimo metai buvo svarbus veiksnys, lemiantis derliaus, mineralinių maisto medžiagų (Fe, Zn ir Mn) ir baltymų frakcijų kiekio bei sudèties (išskyrus didelio molekulinio svorio gluteninus) skirtumus.

Reikšminiai žodžiai: baltymų kiekis, baltymų sudètis, gliadinai, gluteninai, mikroelementai, 'Schwabenkorn'. 